\title{
PENERAPAN MODEL PEMBELAJARAN PROBLEM BASED LEARNING (PBL) UNTUK MENINGKATKAN HASIL BELAJAR SISWA SMP NEGERI 1 RANTAU SELATAN
}

\author{
Mely Sari Situmorang ${ }^{1}$, Katrina Samosir ${ }^{2}$ \\ ${ }^{1,2)}$ FMIPA Unimed Medan \\ email : melysari986@yahoo.co.id
}

\begin{abstract}
ABSTRAK
Penelitian ini bertujuan untuk (1) mengetahui peningkatan hasil belajar matematika siswa dengan menggunakan model pembelajaran PBL (Problem Based Learning) pada materi Sistem Persamaan Linier Dua Variabel di kelas VIII SMP Negeri 1 Rantau Selatan.. Jenis penelitian ini adalah penelitian tindakan kelas (classroom action research). Subjek dalam penelitian ini adalah siswa kelas VIII. Penelitian ini adalah penelitian tindakan kelas yang dilaksanakan dalam 2 siklus yang masing-masing siklus dilaksanakan dalam 2 kali pertemuan. Subjek dalam penelitian ini adalah siswa kelas VIII-2 yang berjumlah 35 orang. Berdasarkan Hasil analisis siklus I dari nilai Test Hasil Belajar I diperoleh nilai rata-ratanya 55,42. Sebanyak 10 siswa $(28,57 \%)$ tuntas dalam belajar sedangkan 25 siswa $(71,42 \%)$ tidak tuntas. Dan hasil analisis siklus II dari nilai Tes Hasil Belajar II nilai rataratanya 72,28 . Sebanyak 31 siswa $(88,57 \%)$ tuntas dalam belajar sedangkan 4 siswa $(11,42 \%)$ tidak tuntas dalam belajar.Ketuntasan belajar siswa secara klasikal dan individu mencapai $88,57 \%$ yang memperoleh nilai $\geq 65$ dan siswa lainnya atau $11,42 \%$ memperoleh nilai $<65$, maka pembelajaran ini dikatakan tuntas. Tingkat penguasaan siswa dari tes belajar II mencapai kriteria tinggi, maka pembelajaran ini dikatakan telah tercapai. Pelaksanaan pembelajaran berdasarkan hasil observasi untuk guru pada siklus I sebesar 2,23 meningkat pada siklus II menjadi 3,02. Berdasarkan hasil penelitian tersebut dapat disimpulkan bahwa Model PBL dapat meningkatkan hasil belajar siswa pada materi sistem linier dua variabel di kelas VIII-2 SMP.

Kata kunci : PBL, Hasil Belajar Matematika, SPLDV
\end{abstract}

\section{ABSTRACT}

This study aims to determine the improvement of mathematics learning outcomes of students by using PBL (Problem Based Learning) model on the material of Two Variable Linear Equation System in class VIII SMP Negeri 1 Rantau Selatan. This type of research is a classroom action research. Subjects in this study were students of class VIII. This study is a classroom action research conducted in 2 cycles which each cycle is held in 2 meetings. Subjects in this study were students of class VIII-2 which amounted to 35 people. Based on the results of the analysis of the cycle I of the value of Test Results I obtained an average score of 55.42. A total of 10 students $(28,57 \%)$ complete in learning while 25 students $(71,42 \%)$ not complete. And the result of analysis of cycle II from test result of result of learning II average value 72,28. A total of 31 students $(88,57 \%)$ complete in learning while 4 students $(11,42 \%)$ not complete in learning. Student learning completeness in class and individual reach $88,57 \%$ which get value of 65 and other student or $11,42 \%$ get value $<65$, then this learning is said to be complete. The level of mastery of students from the test of learning II reaches a high criterion, then this learning is said to have been achieved. Implementation of learning based on observations for teachers in cycle I of 2.23 increased in cycle II to 3.02. Based on the results of this study can be concluded that PBL model can improve student learning outcomes on twovariable linear system material in class VIII-2 SMP.

Mely Sari Situmorang, Katrina Samosir. Penerapan Model Pembelajaran Problem Based Learning (PBL) untuk Meningkatkan Hasil Belajar Siswa SMP Negeri 1 Rantau Selatan. Jurnal Inspiratif, Vol. 4, No. 1 April 2018. 
Keywords: PBL, Mathematics Learning Outcomes, SPLDV

\section{PENDAHULUAN}

Matematika merupakan salah satu bidang studi yang menduduki peranan penting dalam pendidikan,maka upaya untuk meningkatkan kualitas pembelajaran matematika diperlukan perhatian yang serius. Menurut Cornelius (dalam Abdurrahman, 2003:253) alasan perlunya matematika diajarkan kepada siswa karena : (1) sarana berpikir yang jelas dan logis, (2) sarana untuk memecahkan masalah kehidupan sehari-hari, (3) sarana mengenal pola-pola hubungan dan generalisasi pengalaman, (4) sarana untuk mengembangkan kreativitas, dan (5) sarana untuk meningkatkan kesadaran terhadap perkembangan budaya.

Namun, pada kenyataanya hasil pembelajaran matematika masih memprihatinkan.Seperti yang diungkapkan Soekisno (2009):

"Hasil tes diagnostik yang dilakukan oleh Suryanto dan Somerset di 16 sekolah menengah beberapa provinsi di Indonesia menginformasikan bahwa hasil tes pada mata pelajaran matematika sangat rendah. Hasil dari TIMSS-Third International Mathematics and Science Study menunjukkan Indonesia pada mata pelajaran matematika berada di peringkat 34 dari 38 negara."

Hal tersebut sesuai dengan pendapat Noor selaku ketua Asosiasi Guru Matematika Indonesia (AGMI) (2007) mengemukakan bahwa:
"Prestasi matematika siswa kelas 8 di Indonesia masih lebih rendah dibandingkan dengan Malaysia dan Singapura yang jumlah jam pengajarannya setiap tahun lebih sedikit dibandingkan Indonesia.Prestasi matematika di Indonesia memiliki ratarata 411 sedangkan di Malaysia 508 dan di Singapura 605."

Banyak siswa yang memandang matematika sebagai bidang studi yang paling sulit. Hal ini terjadi matematika disajikan dalam bentuk yang kurang menarik dan terkesan sulit untuk dipelajari siswa, akibatnya siswa sering merasa bosan dan tidak merespon pelajaran dengan baik. Selain itu metode pembelajaran yang dilakukan oleh guru kurang bervariasi dan cenderung membatasi siswa untuk berkreasi mengungkapkan pemikirannya saat belajar sehingga siswa kurang berminat belajar matematika dan hasil belajar yang kurang optimal. Seperti yang di kemukakan oleh Abdurrahman (2009:252) bahwa: "Dari berbagai bidang studi yang diajarkan di sekolah, matematika merupakan bidang studi yang dianggap paling sulit oleh para siswa, baik yang tidak berkesulitan belajar, dan lebih-lebih bagi siswa yang berkesulitan belajar". Surya, dkk. (2013) menemukan bahwa kesulitan yang diperoleh siswa adalah pada saat memahami, menggambar diagram, membaca grafik dengan benar, pemahaman konsep matematika formal, dan penyelesaian masalah matematika. Temuan ini juga relevan dengan Novriani, dan Surya (2017).

Pembelajaran matematika dewasa ini masih terkesan kurang menyentuh kepada substansi pemecahan

Mely Sari Situmorang, Katrina Samosir. Penerapan Model Pembelajaran Problem Based Learning (PBL) untuk Meningkatkan Hasil Belajar Siswa SMP Negeri 1 Rantau Selatan. Jurnal Inspiratif, Vol. 4, No. 1 April 2018. 
masalah. Siswa lebih cenderung menghafalkan konsep-konsep matematika sehingga kemampuan siswa dalam memecahkan masalah sangat kurang. Dan siswa selalu bermalasmalasan saja tidak mau mencari sendiri ide-idenya hanya guru saja yang selalu berperan aktif dalam proses belajarmengajar.

Demikian halnya juga ditemukan di sekolah SMP Negeri 1 Rantau Selatan. Dari hasil observasi yang diawali dengan wawancara kepada salah seorang guru matematika mengatakan bahwa :

"Minat belajar sebagian siswa di kelas VIII pada pelajaran Matematika masih kurang bahkan ada juga beberapa siswa yang takut belajar Matematika.Hal ini dapat dilihat dari rendahnya hasil belajar yang diperoleh siswa kelas VIII karena masih banyak siswa yang memperoleh nilai di bawah rata - rata kelas".

Berdasarkan hasil tes yang diberikan terhadap 35 orang siswa kelas VIII-2 SMP Negeri 1 Rantau Selatan, menunjukkan bahwa 1 siswa memiliki nilai $\geq 65$ dan 34 siswa memiliki nilai < 65. Dari hasil pekerjaan siswa diketahui bahwa siswa tidak dapat menyelesaikan masalah yang diberikan sehingga yang terjadi siswa tidak mengerti menyusun langkah awal penyelesaian seperti mengumpulkan informasi yang di peroleh dari masalah tersebut dan siswa kesulitan merencanakan penyelesaiannya sehingga salah atau tidak mampu mengerjakannya. Hanya 1 siswa yang tuntas dalam menyelesaiakan tes sehingga dapat dikategorikan kemampuan siswa sangat rendah.

Dari hasil observasi tersebut dapat disimpulkan bahwa hasil belajar matematika kelas VIII-2 SMP Negeri 1 Rantau Selatan masih belum sesuai dengan apa yang diharapkan. Selain hasil belajarnya yang masih rendah, keaktifan siswa selama proses pembelajaran berlangsung juga masih rendah. Berdasarkan hasil observasi awal, aktivitas belajar siswa selama proses pembelajaran seperti bertanya, mengeluarkan pendapat, menjawab pertanyaan guru, beradu argumen sangat jarang sekali terjadi. Bahkan untuk memperhatikan penjelasan dari guru di depan kelas saja sangat sulit. Mereka kurang bisa mengoptimalkan kemampuan yang ada pada diri mereka. Mereka kurang berani untuk mengeluarkan pendapat, tidak mau menjawab pertanyaan guru sebelum di hukum terlebih dahulu, bahkan mereka malu untuk bertanya sehingga mereka tidak akan pernah mengerti dengan materi yang tidak pernah mereka ketahui akibat malu untuk bertanya.

$$
\text { Banyak faktor yang }
$$
menyebabkan rendahnya hasil belajar matematika siswa diantaranya adalah kurang minat siswa dalam mengikuti pelajaran matematika. Hal ini disebabkan karena adanya anggapan yang kuat pada diri siswa bahwa mata pelajaran matematika sulit dipelajari dan dipahami. Seperti yang diungkapkan Nurhalimah (2009) menyatakan bahwa : "Matematika adalah mata pelajaran yang diangap sulit dalam tiap pembelajarannya.Anggapan tersebut tidak terlepas dari persepsi yang berkembang dalam masyarakat tentang matematika yang dianggap sebagai ilmu yang kering, abstrak, teoritis, penuh dengan lambang-lambang dan rumusrumus yang sulit dan membingungkan. Hal ini akan berdampak buruk terhadap prestasi belajar matematika siswa. Maka

Mely Sari Situmorang, Katrina Samosir. Penerapan Model Pembelajaran Problem Based Learning (PBL) untuk Meningkatkan Hasil Belajar Siswa SMP Negeri 1 Rantau Selatan. Jurnal Inspiratif, Vol. 4, No. 1 April 2018. 
dari itu seorang guru matematika harus terampil dalam penyelenggaraan pembelajaran agar dapat menepis anggapan negatif tentang belajar matematika".

Faktor lain yang

menyebabkan hasil belajar matematika siswa rendah adalah model pembelajaran yang tidak tepat. Seperti yang diungkapkan Nurhayati (2009) bahwa: "Guru matematika saat ini cenderung kurang bervariasi dalam mengajar, latihan yang diberikan kurang bermakna dan umpan balik serta korelasi dari guru jarang diterapkan. Padahal guru merupakan salah satu kunci keberhasilan dalam peningkatan prestasi belajar siswa bahkan merupakan center aktivitas di kelas. Guru bertanggung jawab mengatur, mengelola dan mengorganisir kelas. Oleh karena itu, keberhasilan siswa di kelas yang paling berpengaruh dan dominan adalah guru."

Untuk mengantisipasi masalah tersebut, seorang guru harus mampu memilih model pembelajaran yang tepat sehingga dapat meningkatkan hasil belajar siswa. Di samping itu model pembelajaran yang digunakan harus dapat membuat siswa aktif, karena keaktifan siswa mampu mempengaruhi pengetahuan mereka.

Untuk itu peneliti akan menerapkan model Pembelajaran Problem Based Learning di sekolah ini untuk mengatasi masalah tersebut, terutama meningkatkan hasil belajar siswa dan menjadikan pembelajaran student centered dengan alasan sebagai berikut: 1. Berdasarkan hasil wawancara dengan Ibu Rosmiati,S.Pd, beliau belum pernah menerapkan model pembelajaran berdasarkan masalah didalam pembelajaran matematika, 2. Model
Pembelajaran Problem Based Learning akan melibatkan siswa dalam pola pemecahan masalah yang diberikan guru, dengan melakukan percobaan, tanya jawab dan diskusi. Dengan demikian aktivitas belajar akan tinggi dan proses pembelajaran akan bersifat student centered. Sehingga hasil belajar yang diharapkan dapat tercapai, 3. Model Pembelajaran Problem Based Learning sesuai dengan karakter siswa, yaitu membangkitkan siswa dalam diskusi-diskusi yang selama ini diskusi kurang dominan dalam pembelajaran di sekolah ini,4. model pembelajaran ini juga telah dilakukan oleh peneliti terdahulu dan dari hasil penelitian ternyata model ini dapat meningkatkan hasil belajar siswa.

\section{METODE PENELITIAN}

Penelitian ini dilaksanakan di SMP Negeri 1 Rantau Selatan dengan waktu pelaksanaan pada tahun ajaran 2017/2018 di kelas VIII semester Ganjil. Adapun alasan pemilihan lokasi ini karena hasil belajar matematika siswa pada sekolah tersebut rendah.

Subjek dalam penelitian ini adalah siswa kelas VIII-2 SMP. Objek penelitian ini adalah penerapan model pembelajaran PBL ( Problem Based Learning) untuk meningkatkan hasil belajar siswa pada pokok bahasan statistika di kelas VIII SMP Negeri 1 Rantau Selatan.

Jenis penelitian ini adalah penelitian tindakan kelas (classroom action research) dengan menerapkan model pembelajaran berbasis masalah dengan tujuan memperbaiki mutu praktik pembelajaran di kelas. Penelitian ini bertujuan untuk mengungkap kesulitan yang dialami siswa dalam menyelesaikan menyelesaikan soal-soal

Mely Sari Situmorang, Katrina Samosir. Penerapan Model Pembelajaran Problem Based Learning (PBL) untuk Meningkatkan Hasil Belajar Siswa SMP Negeri 1 Rantau Selatan. Jurnal Inspiratif, Vol. 4, No. 1 April 2018. 
persamaan linier dua variabel dengan tujuan untuk meningkatkan hasil belajar siswa pada pokok bahasan Persamaan Linier Dua Varibel. .
Secara lebih rinci, prosedur pelaksanaan penelitian tindakan kelas dapat digambarkan sebagai berikut :

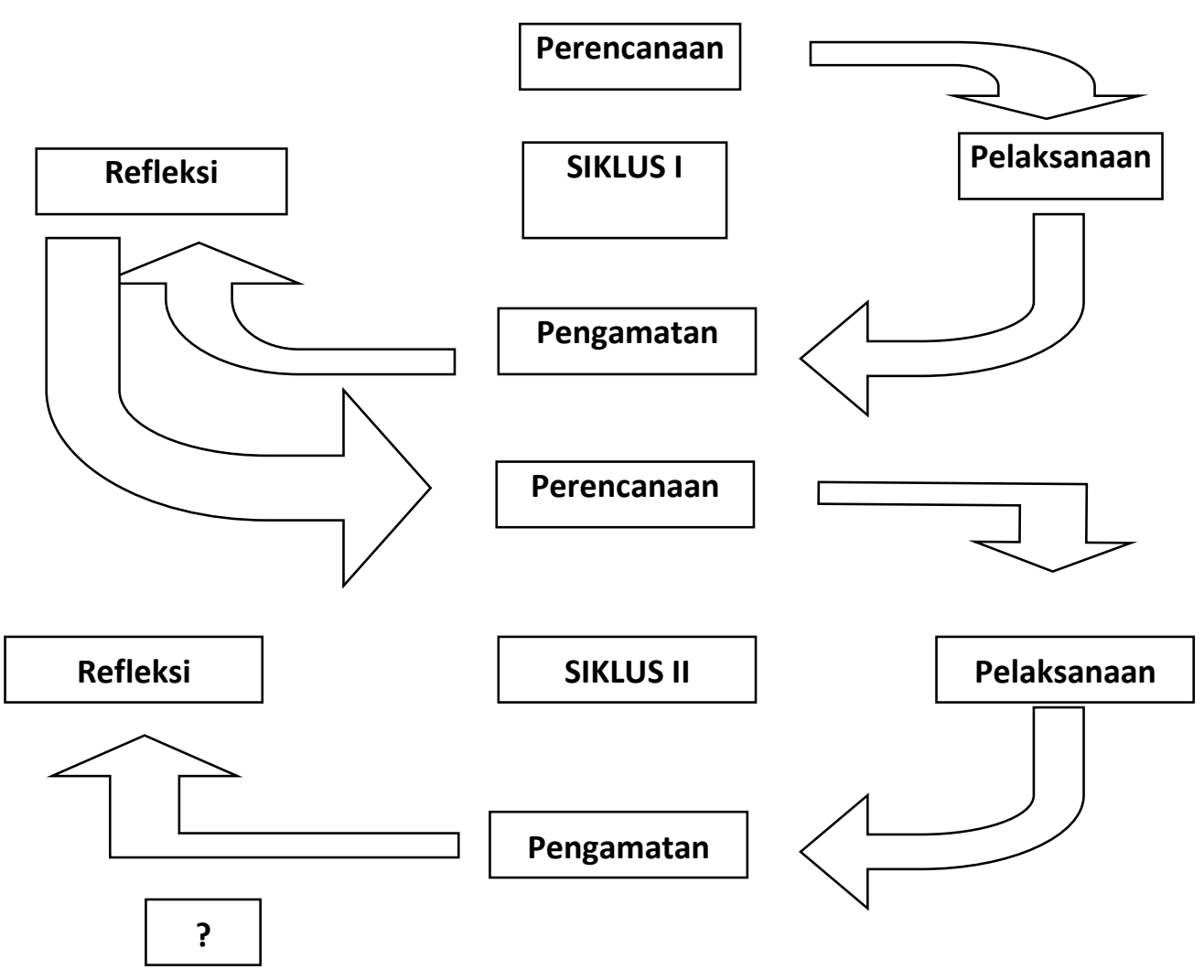

Gambar 1. Alur dalam Penelitian Tindakan Kelas

\section{HASIL DAN PEMBAHASAN}

Observasi dilaksanakan ketika proses penerapan model PBL (Problem Based Learning) dalam pembelajaran matematika pada materi SPLDV setiap kali pertemuan. Dari lembar observasi yang telah diisi oleh observan tiap kali pertemuan, data observasi dapat dilihat pada lampiran. Berdasarkan perhitungan rata-rata keseluruhan aspek berada pada nilai 2,23 - 3,02. Maka dapat simpulkan pembelajaran dengan penerapan model PBL (Problem Based Learning) pada materi SPLDV dalam penelitian ini berjalan dengan baik.

\section{Hasil Belajar Siswa}

Penerapan model PBL (Problem Based Learning) masalah dapat meningkatkan hasil belajar matematika siswa. Berdasarkan hasil penelitian, sebelum diberi tindakan rata-rata kelas adalah 41,14 dengan tingkat ketuntasan klasikal 2,86\%. Setelah diberi tindakan I menggunakan model PBL (Problem Based Learning), rata-rata nilai Tes Hasil Belajar I meningkat menjadi 55,42

Mely Sari Situmorang, Katrina Samosir. Penerapan Model Pembelajaran Problem Based Learning (PBL) untuk Meningkatkan Hasil Belajar Siswa SMP Negeri 1 Rantau Selatan. Jurnal Inspiratif, Vol. 4, No. 1 April 2018. 
dengan persentase ketuntasan klasikal $28,57 \%$. Ini berarti terjadi peningkatan $25,71 \%$ dari tes diagnostik yang dilaksanakan. Kemudian setelah pemberian tindakan II dimana pembelajaran masih tetap dengan model sebesar 16,86\% dari Tes Hasil Belajar I.

\section{Ketuntasan Belajar Siswa}

PBL (Problem Based Learning) diperoleh rata-rata Tes Hasil Belajar II siswa adalah 72,28 dengan persentase ketuntasan klasikal $88,57 \%$ yang berarti mengalami peningkatan

Berdasarkan hasil tes yang diberikan pada siklus I dan siklus II selama penelitian maka diperoleh tingkat ketuntasan sebagai berikut :

Tabel 1. Tingkat Ketuntasan Tes Awal, THB I dan THB II

\begin{tabular}{|l|c|c|c|}
\hline & Tes Diagnostik & THB I & THB II \\
\hline $\begin{array}{l}\text { Siswa yang } \\
\text { tuntas }\end{array}$ & $\begin{array}{l}\text { 1 Siswa } \\
(2,86 \%)\end{array}$ & $\begin{array}{l}\text { 10 Siswa } \\
(28,57 \%)\end{array}$ & $\begin{array}{l}\text { 31 Siswa } \\
(88,57 \%)\end{array}$ \\
\hline $\begin{array}{l}\text { Siswa yang } \\
\text { tidak tuntas }\end{array}$ & 34 Siswa & 25 Siswa & 4 Siswa \\
$(97,24 \%)$ & $(71,42 \%)$ & $71,42 \%)$ \\
\hline Nilai rata-rata & 41,14 & 55,42 & SPLDV di kelas VIII-2 dengan \\
\multicolumn{2}{|r|}{ Berdasarkan tabel di atas, dapat } & menggunakan model PBL (Problem \\
dilihat bahwa banyak siswa yang tuntas & Based Learning) telah tuntas. \\
dalam pembelajaran mulai dari tes awal
\end{tabular}

hingga tes hasil belajar II terus mengalami peningkatan yang pada awalnya hanya 1 siswa menjadi 10 hingga 31 siswa. Nilai rata-rata siswa meningkat dari tes awal yang hanya 41,14 menjadi 71,28. Karena sebanyak $88,57 \%$ dari keseluruhan siswa telah tuntas, maka pembelajaran pada materi

\section{Tingkat Penguasaan Siswa}

Berdasarkan hasil tes yang diberikan dari tes awal sampai siklus II, maka tingkat penguasaan siswa dapat diperoleh. Hasil selengkapnya dapat dilihat pada tabel berikut :

Tabel 2 . Deskripsi Tingkat Kemampuan Siswa Setiap Siklus

\begin{tabular}{|c|c|c|c|c|}
\hline $\begin{array}{c}\text { Tingkat } \\
\text { Penguasaan }\end{array}$ & Kriteria & Tes Diagnostik & THB I & THB II \\
\hline $90 \%-100 \%$ & Sangat tinggi & - & 2 & 4 \\
\hline $80 \%-89 \%$ & Tinggi & - & 2 & 8 \\
\hline $65 \%-79 \%$ & Sedang & 1 & 7 & 19 \\
\hline $55 \%-64 \%$ & Rendah & 6 & 7 & - \\
\hline $0 \%-54 \%$ & Sangat rendah & 28 & 17 & 4 \\
\hline$\sum \quad 35$ & 35 & 35 \\
\hline \multicolumn{2}{l|}{} & 41,14 & 55,42 & 72,28 \\
\hline Pata-rata kelas & $2,86 \%$ & $28,57 \%$ & $88,57 \%$ \\
\hline Persentase ketuntasan klasikal & $97,24 \%$ & $71,42 \%$ & $11,42 \%$ \\
\hline
\end{tabular}

Setelah pelaksanaan model PBL, langkah- langkah Berdasarkan tabel di atas dapat dilihat bahwa banyaknya siswa yang memiliki tingkat penguasaan

Mely Sari Situmorang, Katrina Samosir. Penerapan Model Pembelajaran Problem Based Learning (PBL) untuk Meningkatkan Hasil Belajar Siswa SMP Negeri 1 Rantau Selatan. Jurnal Inspiratif, Vol. 4, No. 1 April 2018. 
sangat rendah mulai tes diagnostik sampai tes hasil belajar II terus berkurang dari 28 siswa menjadi 17 siswa pada Tes Hasil Belajar I dan menjadi 4 siswa yang memiliki tingkat penguasaan sangat rendah pada Tes Hasil Belajar II. Siswa yang memiliki tingkat penguasaan rendah mulai tes diagnostik sampai Tes Hasil Belajar II terus berkurang dari 6 siswa menjadi 7 siswa pada Tes Hasil Belajar I dan menjadi tidak ada lagi siswa yang memiliki tingkat penguasaan rendah pada Tes Hasil Belajar II. Siswa yang memiliki tingkat penguasaan sedang pada saat tes diagnostik yang hanya 1 siswa bertambah menjadi 7 siswa pada Tes Hasil Belajar I, namun bertambah menjadi 19 siswa pada Tes Hasil Belajar II. Siswa yang tidak memiliki tingkat penguasaan tinggi pada tes awal tidak ada siswa dan dari Tes Hasil Belajar I terdapat 2 siswa, namun bertambah pada Tes Hasil Belajar II terdapat 8 siswa yang memiliki tingkat penguasaan tinggi. Siswa yang tidak memiliki tingkat penguasan sangat tinggi pada tes awal tidak ada dan dari Tes Hasil Belajar I terdapat 2 siswa, namun betamabah pada Tes Hasil Belajar II terdapat 2 siswa memiliki tingkat penguasaan sangat tinggi. Walaupun masih ada 4 siswa yang tidak tuntas pada Tes Hasil Belajar II, namun secara keseluruhan tingkat penguasaan di kelas ini termasuk ke dalam kategori tinggi yaitu dilihat dari rata-rata siswa pada Tes Hasil Belajar II yaitu 72,28.

Berdasarkan perolehan nilai pada siklus pertama dan siklus kedua, disimpulkan bahwa hasil belajar siswa mengalami peningkatan. Pada penerapan model pembelajaran Problem Based Learning siswa dituntut untuk melakukan proses yang membawa mereka kepada suatu tingkat pemahaman yang lebih dalam terhadap materi yang diajarkan dan pada proses pembelajaran sangat dituntut untuk diskusi dan bekerja sama. Bekerja sama dapat memberikan motovasi dan memperbanyak peluang untuk bertukar pengalaman dan juga keterampilan social. Hal ini didukung oleh teori Vygotsky yang menekankan pada aspek social dari pembelajaran. Vygostky menyatakan bahwa proses pembelajaran akan terjadi jika anak bekerja, menangani tugas yang belum dipelajari, namun tugas itu masih berada dalam jangkauan mereka yaitu daerah tingkat perkembangan sedikit di atas daerah perkembangan saat ini. Vygostky juga menekankan adanya "scaffolding" yang berarti memberikan anak sejumlah besar bantuan selama tahap- tahap awal pembelajaran dan kemudian mengurangi bantuan dan memberikan kesempatan kepada anak tersebut untuk mengambil alih tangggung jawab yang semakin besar yakni menyelesaikan sendiri masalah tersebut. Hubungan teori ini dengan model pembelajaran berdasarkan masalah yaitu interaksi social bahwa siswa diperkenankan melakukan pekerjaan dengan berkelompok kecil serta merangsang siswa agar aktif untuk bertanya dan berdiskusi.

Selain itu, penelitian ini juga didukung oleh penelitian yang dilakukan oleh Kenro (2009) menunjukkan bahwa, kemampuan pemecahan masalah matematika siswa dengan PBM lebih baik dari pada yang diajarkan dengan konvensional pada siswa kelas VIII SMP Sw RK Bintang Samosir Palipi T.A. 2008/2009. Ia menyimpulkan bahwa rata-rata kemampuan pemecahan masalah matematika siswa yang diajarkan dengan PBM pada pokok

Mely Sari Situmorang, Katrina Samosir. Penerapan Model Pembelajaran Problem Based Learning (PBL) untuk Meningkatkan Hasil Belajar Siswa SMP Negeri 1 Rantau Selatan. Jurnal Inspiratif, Vol. 4, No. 1 April 2018. 
bahasan aritmatika sosial lebih baik jika dibandingkan dengan pembelajaran dengan menggunakan konvensional. Sejalan dengan itu, penelitian yang dilakukan Sidabariba (2010) menunjukkan bahwa, terdapat peningkatan kemampuan pemecahan masalah matematika siswa kelas VIII SMP N 10 Pematangsiantar T.A. 2009/2010 dengan menerapkan model pembelajaran PBM. Ia menyimpulkan bahwa pembelajaran dengan menerapkan model pembelajaran PBM mendorong siswa aktif berpartisipasi dalam proses pembelajaran dan meningkatkan kemampuan pemecahan masalah matematika. Dari kedua hasil penelitian ini diperoleh bahwa model pembelajaran berdasarkan masalah dapat meningkatkan kemampuan pemecahan masalah matematika siswa. Penelitian ini juga relevan dengan temuan Surya dan Syahputra (2017) PBL dapat meningkatkan berpikir tingkat tinggi siswa.

Secara teoritis model pembelajaran berdasarkan masalah memiliki beberapa keunggulan. Apabila keunggulan ini mampu dimaksimalkan dalam kegiatan belajar mengajar di kelas akan meningkatkan aktivitas dan hasil belajar matematika siswa. Keunggulan tersebut dapat diuraikan sebagai berikut:

1. Pembelajarannya lebih menarik sehingga mendorong siswa untuk dapat terjun ke dalamnya.

2. Dapat menciptakan kerjasama (interaksi) yang baik diantara siswa.

3. Memberikan kesempatan kepada siswa untuk mengaplikasikan pengetahuan mereka dalam dunia nyata.

Dari pembahasan di atas, adanya penelitian yang relevan, teori belajar yang mendukung dan keunggulan yang dijelaskan peneliti di atas ditemukan bahwa model pembelajaran Problem Based Learning mampu meningkatkan hasil belajar siswa.

\section{Temuan Penelitian}

Berdasarkan hasil penelitian dan pengolahan data, peneliti menemukan hal-hal sebagai berikut :

1) Pada siklus I, setelah pemberian tindakan pengajaran melalui model PBL (Problem Based Learning), siswa diberi tes hasil belajar di kelas VIII-2, diperoleh 10 siswa telah mencapai ketuntasan belajar yang diharapkan sedangkan 25 siswa lainnya belum mencapai tingkat ketuntasan belajar dengan nilai rata-rata pada kelas VIII-2 mencapai 55,42 dengan ketuntasan klasikal yang diperoleh sebesar $28,57 \%$. Pada siklus ini ada beberapa siswa yang kurang aktif pada saat pembelajaran berlangsung sehingga tidak mencapai nilai tingkat ketuntasan belajar. Jika dilakukan dengan tepat, tentu saja kelebihan model pembelajaran berbasis masalah seperti yang diungkapkan pada bab II sebelumnya akan tercapai. Namun, jika sebaliknya akan ditemukan kekurangan-kekurangan seperti konsep yang tidak ditemukan dan memakan waktu yang lama menyebabkan peneliti tidak tepat waktu seperti yang sudah ditetapkan pada RPP.

2) Setelah pemberian tindakan pada siklus II di kelas VIII-2, siswa diberi tes hasil belajar maka diperoleh 31 siswa telah mencapai ketuntasan belajar yang diharapkan sedangkan 4 siswa lainnya belum mencapai tingkat ketuntasan belajar. Pada siklus II ini siswa terlihat lebih aktif dalam pembelajaran setelah

Mely Sari Situmorang, Katrina Samosir. Penerapan Model Pembelajaran Problem Based Learning (PBL) untuk Meningkatkan Hasil Belajar Siswa SMP Negeri 1 Rantau Selatan. Jurnal Inspiratif, Vol. 4, No. 1 April 2018. 
diberikan penambahan media power point sehingga diperoleh nilai rata-rata pada kelas VIII-2 mencapai 72,28 dengan ketuntasan klasikal yang diperoleh sebesar $88,57 \%$ yang berarti mengalami peningkatan nilai rata-rata hasil belajar siswa dari siklus I dan siklus II sebesar 16,86 dan peningkatan ketuntasan belajar siswa secara klasikal sebesar $60 \%$.

3) Berdasarkan perhitungan hasil observasi proses pembelajaran, diperoleh rata-rata keseluruhan aspek adalah 2,56 - 3,21. Sehingga proses pembelajaran berlangsung baik.

Berdasarkan temuan-temuan penelitian maka dapat dikatakan bahwa penerapan model PBL (Problem Based Learning) dapat meningkatkan hasil belajar matematika siswa. Dari hasil penelitian di atas membenarkan teori yang menyatakan bahwa salah satu model pembelajaran yang dinilai mampu meningkatkan hasil belajar matematika siswa adalah model PBL (Problem Based Learning), karena melalui permasalahan sehari-hari siswa lebih mudah untuk memahami materi yang disampaikan. Penerapan model PBL (Problem Based Learning) sejalan dengan teori belajar Jerome S. Bruner. Dengan ide utamanya bahwa siswa dalam belajar menemukan kembali, bukan menemukan yang sama sekali benar-benar baru, kemudian siswa belajar penemuan sesuai dengan pencarian pengetahuan secara aktif oleh manusia.

Untuk memperkuat hasil penelitian ini maka dibandingkan dengan penelitian yang relevan yang dilakukan Dari hasil di atas maka dapat disimpulkan model PBL (Problem
Based Learning) dapat meningkatkan hasil belajar matematika siswa pada materi statistika di kelas VIII-2 SMP Negeri 1 Rantau Selatan T.A. 2017/2018.

\section{KESIMPULAN DAN SARAN}

Berdasarkan hasil penelitian
yang diperoleh dari analisis data
diperoleh kesimpulan bahwa model
pembelajaran Problem Based Learning (PBL) dapat meningkatkan hasil belajar siswa pada pokok bahasan sistem persamaan linear dua variabel di kelas VIII SMP Negeri 1 Rantau Selatan T.A.2017/2018. Ini dapat dilihat pada tes diagnostic sebelum diberikan model pembelajaran Problem Based Learning (PBL), rata-rata hasil belajar siswa adalah 41,14, hasil belajar setelah tindakan I diberikan (siklus I) nilai ratarata kelas adalah 55,42 dan meningkat pada siklus II menjadi 72,48 sehingga diperoleh peningkatan rata-rata hasil belajar siswa sebesar 16,86. Sedangkan peningkatan hasil belajar siswa secara klasikal yaitu sebesar 28,57\% pada siklus I dan pada siklus II meningkat sebesar $60 \%$ yaitu $88,57 \%$ sudah mencukupi syarat ketuntasan klasikal yaitu $\geq 85 \%$ siswa yang mencapai tes hasil belajar $\geq 65$. Dengan melihat hasil penelitian ini penulis mengajukan beberapa saran kepada guru, khususnya guru matematika sebaiknya menerapkan Model Pembelajaran Berbasis Masalah sebagai salah satu upaya untuk meningkatkan hasil belajar matematika siswa dalam proses pembelajaran di dalam kelas. Bagi peneliti lanjutan yang berminat melakukan penelitian dengan objek yang sama dengan penelitian ini, agar hasil dan perangkat penelitian ini

Mely Sari Situmorang, Katrina Samosir. Penerapan Model Pembelajaran Problem Based Learning (PBL) untuk Meningkatkan Hasil Belajar Siswa SMP Negeri 1 Rantau Selatan. Jurnal Inspiratif, Vol. 4, No. 1 April 2018. 
dapat dijadikan pertimbangan untuk menerapkan model pembelajaran berbasis masalah dalam proses pembelajaran pada materi statistika ataupun pokok bahasan yang lain. Disarankan untuk mengembangkan penelitian ini dengan mempersiapkan pembelajaran model pembelajaran berbasis masalah yang lebih baik dan meningkatkan penguasaan kelas.

\section{DAFTAR PUSTAKA}

Abdurrahman, M. 2003.Pendidikan Bagi Anak Berkesulitan Belajar, Penerbit Rineka Cipta, Jakarta.

Adinawan, M. 2006.Matematika Untuk SMP Jilid $2 A$ Kelas VIII, Erlangga, Jakarta.

Amir, T. 2009.Inovasi Pendidikan Melalui Problem Based Learning,Kencana, Jakarta.

Bungel, Moh. Fikri, (2014), Penerapan Model Pembelajaran Problem Based Learning untuk Meningkatkan Hasil Belajar Siswa pada Siswa Kelas VIII SMP Negeri 4 Palu pada Materi Prisma, Jurnal Elektronik Pendidikan Matematika Tadulako, Vol. 2, Nomor 1

Djamarah, S.B.2006.Strategi Belajar Mengajar,Penerbit Rineka Cipta, Jakarta.

Erman, S. 2009.Pendekatan Kontekstual Dalam Pembelajaran Matematik, (http://educare.e-fkipunla.net) diakses 23 juli 2012.

Fakultas Matematika dan Ilmu Pengetahuan Alam Universitas Negeri, (2010). Buku Pedoman Penulisan Proposal dan Skripsi
Mahasiswa Program Studi Pendidikan, FMIPA Unimed.

Ibrahim, M, dkk, 2000.Pembelajaran Kooperatif, Penerbit University Press, Surabaya.

Nasution,P.R, dkk.2015. Dan di SMPN 4 Padangsidimpuan. Jurnal Pendidikan Matematika Paradigma.Vol 8 No.3.

Novriani, M. R., Surya, E. 2017. Analysis of Student Difficulties in Mathematics Problem Solving Ability at MTs SWASTA IRA Medan, International Journal of Sciences Basic and Applied Research (IJSBAR), 33(3), 63-75.

Rusman. 2012.Belajar dan Pembelajaran Berbasis Komputer.Alfabeta: Bandung.

Sanjaya, W. 2008.Strategi Pembelajaran Berorientasi Standar Proses Pendidikan, Kencana, Jakarta.

Sardiman. 2011. Interaksi Dan Motivasi Belajar-Mengajar, Grafindo, Jakarta.

Slameto. 2003. Belajar dan FaktorFaktor yang Mempengaruhinya. Jakarta: Rineka Cipta. 2010.Belajar dan FaktorFaktor yang Mempengaruhinya, Rineka Cipta, Jakarta.

Sudjana,N. 2009. Penilaian Hasil Proses Belajar Mengajar,Remaja Rosdakarya, Bandung.

Sukino, dan Wilson, S. 2006. Matematika untuk SMP kelas VIII, Penerbit Erlangga, Jakarta 
Suprijono, A. 2009.Cooperative Learning Teori \& Aplikasi Paikem, Pustaka Belajar, Yogyakarta.

Surya, E. Sabandar, J. Kusumah, Y.S. dan darhim, 2013. Improving of Junior High School Visual Thinking Representation Ability in Mathematical Problem Solving by CTL. Journal on Mathematics Education, 4(1), 113-126.

Surya, E. and Syahputra, E. 2017. Improving High-Level Thinking Skills by Development of Learning PBL Approach on The Learning Mathematics for Senior High School Students.
International Education Studies, 10(8), 12-20.

Trianto. M. 2007. Model-model Pembelajaran Inovatif Berorientasi Konstruktivistik. Prestasi Pustaka, Jakarta.

.2010 ,

Mendesain

Pembelajaran Inovatif-Progresif, Kencana, Jakarta.

Yuniara ,dkk.2017. Application of Problem Based Learning to Students' Improving on Mathematics Concept of Ability. Internasional Journal of Sciences : Basic and Applied Research (IJSBAR),33 (03).pp.261269.ISSN 2307-4531 